\title{
Myrtillocactus (cactaceae): botanical, agronomic, physicochemical and chemical characteristics of fruits
}

David HeRnÁNDEZ-LóPEZ ${ }^{1}$, Fabrice VAILLANT ${ }^{2}$, Rosalia REYNOSO-CAMACHO ${ }^{3}$, Salvador-Horacio GUZMAN-MALDONADO ${ }^{4 *}$

${ }^{1}$ Dep. Ing. Bioquím., Inst. Tecnol. Celaya, Guanajuato, Mexico

2 CIRAD, UMR Qualisud, TA B-95 / 16, 34398 Montpellier, France

${ }^{3}$ Univ. Autón. Querétaro (APROPAC), Cent. Univ., Querétaro, Qro., Mexico

${ }^{4}$ Unidade Biotecnol. Campo Exp. Bajío, INIFAP, Celaya, Gto., Mexico

guzman.horacio@inifap.gob.mx

${ }^{*}$ Correspondence and reprints

Received 3 January 2008 Accepted 16 April 2008

Fruits, 2008, vol. 63, p. 269-276 (C) 2008 Cirad/EDP Sciences All rights reserved DOI: $10.1051 /$ fruits:2008042 www.fruits-journal.org RESUMEN ESPAÑOL, p. 276
Myrtillocactus (cactaceae): botanical, agronomic, physicochemical and chemical characteristics of fruits.

Abstract - Introduction. In Mexico, the Myrtillocactus fruit production levels are substantial, yet fruits are often under-used. Although the focus of interest is on their potential as food colourings, the fruits deserve more attention for their other food properties but information on their physico-chemical composition is scarce. To offer a baseline for the development of Myrtillocactus cultivation, we reviewed the information so far available. Botanical description. Four Myrtillocactus species have been identified and reported in the literature. They differ in shape, colour and other phenotypic characteristics. In Mexico, the predominant species is $M$. geometrizans, but $M$. schenckii also grows abundantly throughout the arid and semi-arid lands of the country. Cytological analyses performed on M. geometrizans showed that the plant is diploid $(2 n=22)$. Agronomic aspects. Myrtillocactus species belong to the Cactaceae family. Because of their Crassulacean acid metabolism, they are able to grow in the arid and semi-arid highlands of Mexico. $M y r-$ tillocactus species have been propagated asexually by explants or cloning. Under controlled conditions, in vitro micropropagation from apical and basal explants gives rise to high yields. For cultivation, attention should be paid especially to minimum winter temperatures. Description of fruits and biochemical characterisation. The edible fruit is globular, with diameters reaching $1.5 \mathrm{~cm}$. The pulp is gel-like, ranging in colour from glowing red to bluish. Chemical characterisation has mainly focused on betalain compounds, the predominant ones of which are betanin and betaxanthins. Contents are reported to be about $2.3 \mathrm{mg}$ betalain $100 \mathrm{~g}^{-1}$ of pulp. Colour appears to be more stable than for red beets. Human consumption and commercial importance. In the production season (June to September), the fruits are found in all public markets in the states where they are grown. They are eaten either fresh or in processed forms. The commercialisation of the fruit is restricted mainly to rural production areas in certain states of Mexico. Conclusions. Our review establishes that published information on Myrtillocactus species is scarce and incomplete. The plant is under-utilised, despite its nutritional properties and commercial potential. Because they adapt easily to severely dry conditions, the Myrtillocactus species merit much more research.

Mexico / Myrtillocactus / fruits / pigments / agronomic characters

\section{Caractéristiques botaniques, agronomiques, physico-chimiques et} chimiques des fruits de Myrtillocactus (cactaceae).

Résumé - Introduction. Au Mexique, la production de fruits de Myrtillocactus est importante, pourtant ceux-ci sont souvent sous-utilisés. Bien qu'ils soient essentiellement exploités pour leur potentiel de colorants alimentaires, les fruits mériteraient davantage d'attention quant à leurs autres propriétés pour l'alimentation, mais les informations sur leur composition physico-chimique sont rares. Afin de disposer d'éléments de base pour le développement de la culture de Myrtillocactus, nous avons étudié les informations accessibles à ce jour. Description botanique. Quatre espèces de Myrtillocactus ont été identifiées et rapportées dans la littérature. Elles diffèrent par la forme, la couleur, et d'autres caractéristiques phénotypiques. Au Mexique, l'espèce prédominante est $M$. geometrizans, mais $M$. schenckii se développe également abondamment dans toutes les terres arides et semi-arides du pays. Les analyses cytologiques effectuées sur M. geometrizans ont montré que la plante était diploïde $(2 n=22)$. Aspects agronomiques. Le genre Myrtillocactus appartient à la famille des cactacées. En raison de son métabolisme crassulacéen acide, la plante peut se développer dans les montagnes arides et semi-arides du Mexique. Les espèces de Myrtillocactus sont propagées asexuellement par explants ou par clonage. En conditions contrôlées, la micropropagation in vitro d'explants apicaux et basaux donne de hauts rendements. Pour la culture, une attention particulière doit être apportée aux températures hivernales minimales. Description des fruits et caractérisation biochimique. Le fruit comestible est globulaire, avec un diamètre atteignant $1,5 \mathrm{~cm}$. La pulpe est colloïdale, sa couleur va du rougeoyant au rouge bleuâtre. La caractérisation chimique a principalement porté sur la composition en bétalaines, dont les composés prédominants sont la bétanine et les bétaxanthines. La teneur en bétalaines serait de $2,3 \mathrm{mg} \cdot 100 \mathrm{~g}^{-1}$ de pulpe. Le colorant semble être plus stable que celui des betteraves rouges. Consommation humaine et importance commerciale. Pendant la saison de production (juin à septembre), les fruits sont trouvés sur tous les marchés de leur lieu de production. Ils sont mangés frais ou transformés. La commercialisation du fruit est limitée principalement aux zones de production rurales dans certains états du Mexique. Conclusions. Notre synthèse a établi que les informations publiées sur Myrtillocactus étaient rares et incomplètes. La plante est sous utilisée, en dépit de ses propriétés alimentaires et de son potentiel commercial. Comme les espèces de Myrtillocactus s'adaptent facilement dans des conditions de grande sécheresse, elles mériteraient de faire l'objet de beaucoup plus de recherche.

Mexique / Myrtillocactus / fruits / pigment / caractère agronomique 
Figure 1.

Plant of Myrtillocactus geometrizans (Console, 1897).

Plant of Myrtillocactus schenckii (Britton and Rose, 1920).
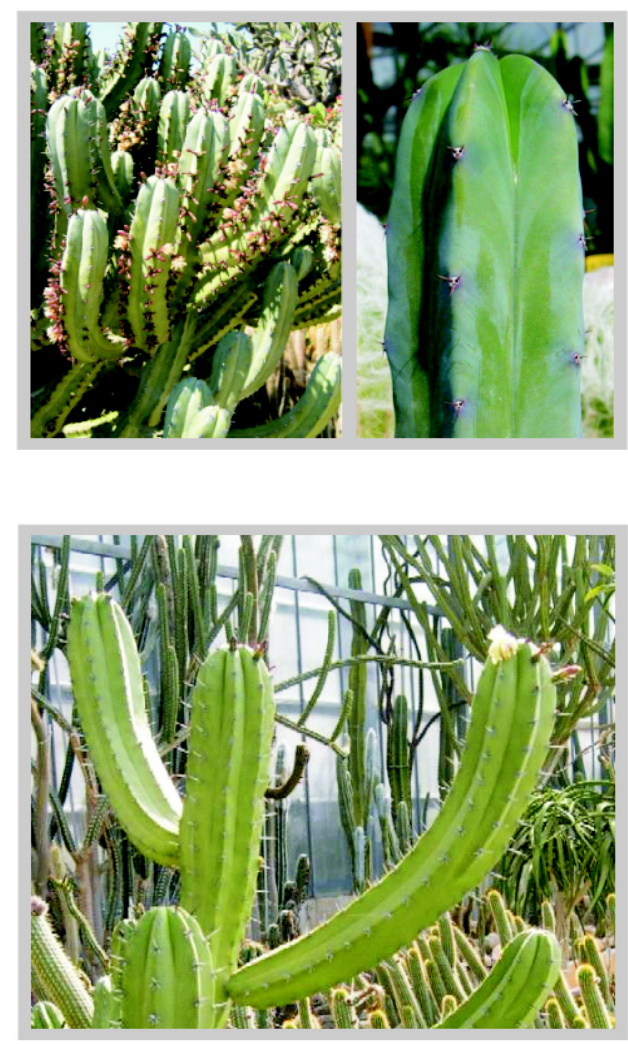

\section{Introduction}

Mexico is richly biodiverse, having 10\% of the planet's total biodiversity. This includes various endemic species that are particularly well adapted to the edapho-climatic conditions found in specific regions of the country. For example, cacti of the Myrtillocactus genus grow in northern Mexico, which has arid or semi-arid regions that are unsuitable for agriculture. Because these plants have high nutritional value and can produce well without formal agronomic management, they are also suitable for niche fruit markets. Myrtillocactus species are also known as the blueberry or whortleberry cacti, being named after these plants for the similarity in size and colour of their respective fruits. Locally, they are known as garambullo. Production levels in Mexico are substantial, yet fruits are often under-used or consumed only locally. The agri-food sector's recent and growing interest in novel foods makes assessing the commercial potential of cactus fruits relevant. Although the focus of interest is on their potential as food colourings, the fruits deserve more attention for their other food properties. Information on the physico-chemical composition of Myrtillocactus fruits is scarce. Nor has much information been assessed to evaluate the agri-food chain. Nothing has been published on processing to obtain added-value products. These areas must be researched if a more formal production sector for Myrtillocactus fruits is to be developed. To offer a baseline for such a project, we reviewed the information so far available.

\section{Botanical description}

Four Myrtillocactus species have been identified and reported in the literature: Myrtillocactus geometrizans [1] (figure 1) and M. schenckii [2] (figure 2), which grow in the arid and semi- arid lands of Mexico; Myrtillocactus eichlamii, a species endemic to Guatemala [2] (figure 3); and M. cochal, which grows in Todos Santos Bay, Baja California, Mexico [3] (figure 4).

The four species differ in shape, colour and other phenotypic characteristics (table I). The predominant Myrtillocactus species growing in the Tehuacán Valley near Mexico City is $M$. geometrizans $[4,5]$. This species is also reported as prevalent in the arid and semi-arid regions of the states of Guanajuato, Hidalgo, Querétaro and San Luis Potosí, and in highly restricted areas of the states of Chihuahua, Jalisco, Michoacán, Oaxaca, Puebla and Tlaxcala [6] (figure 5). Even so, no botanical evaluation has yet been performed [5]. Myrtillocactus schenckii also grows abundantly throughout the arid and semi-arid lands of Mexico [2].

The biodiversity of Myrtillocactus species in Mexico is now being analysed. Preliminary results, using molecular marker methodology (amplified fragment length polymorphism or AFLP), have confirmed the presence of only two differentiated species. These probable correspond to $M$. geometrizans and M. schenckii. Cytological 


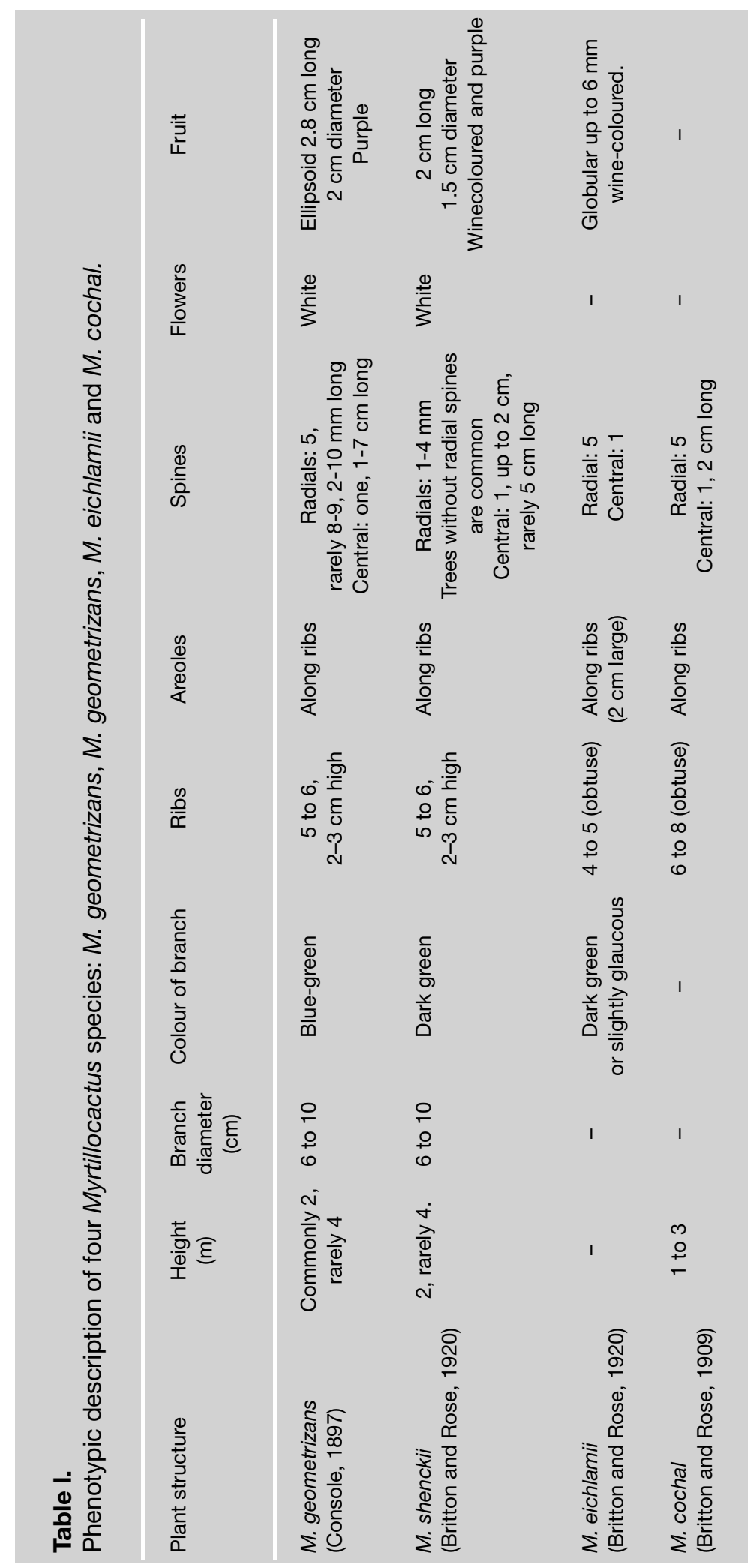

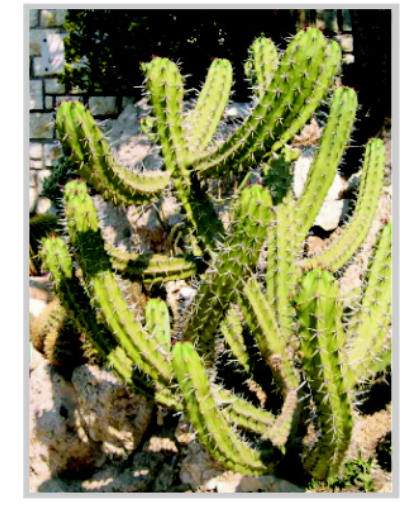

Figure 4.

Plant of Myrtillocactus cochal (Britton and Rose, 19090). 


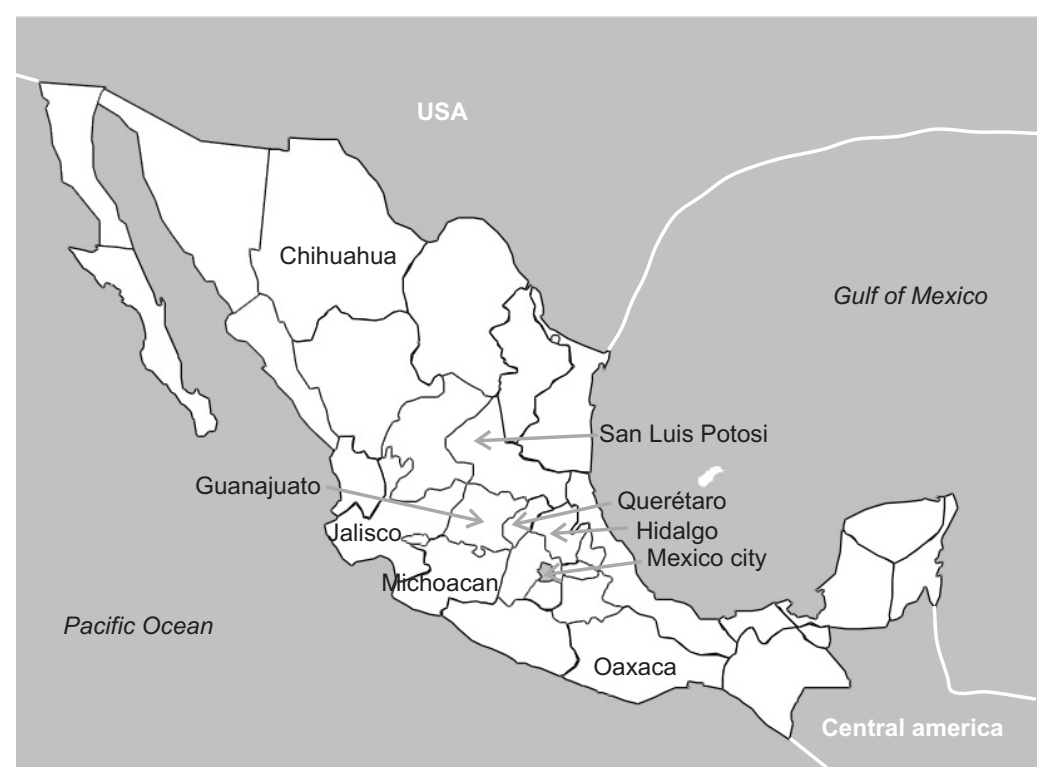

Figure 5.

States of Mexico where Myrtillocactus geometrizans and M. shenckii grow.

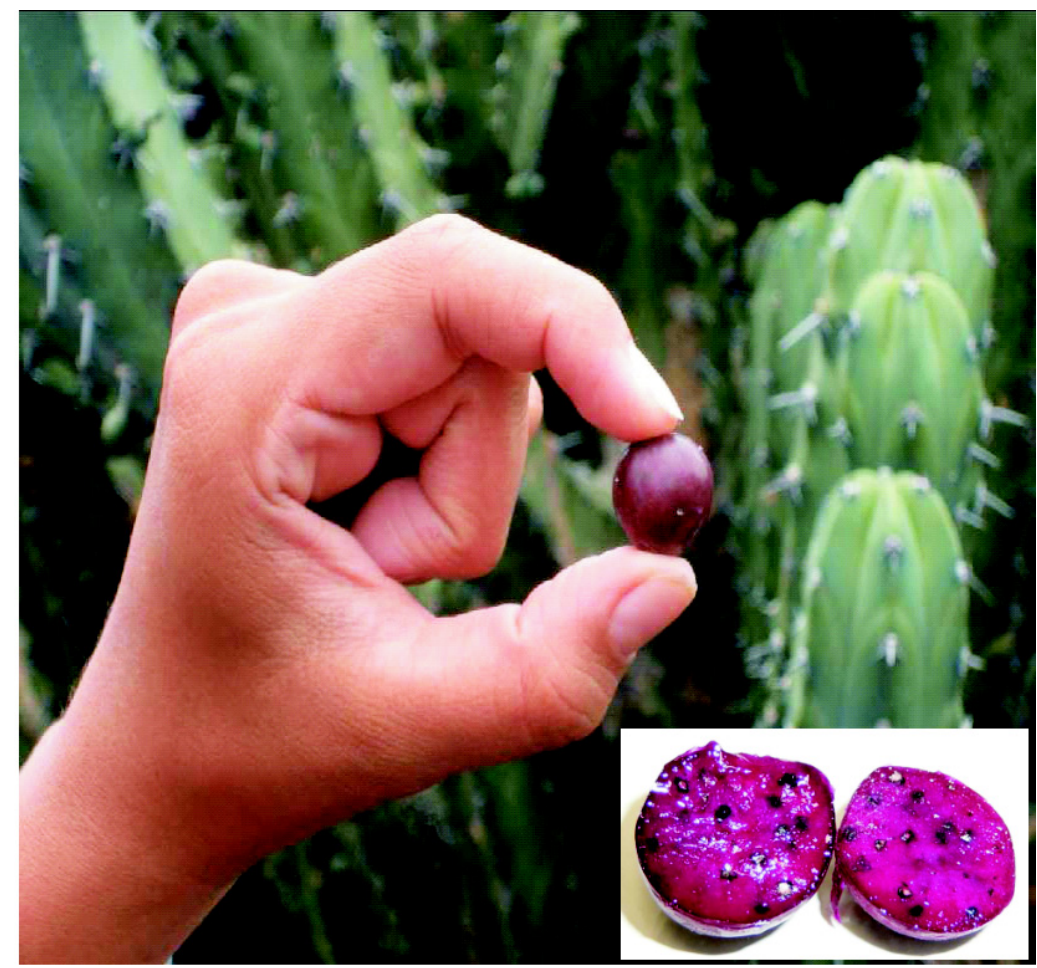

Figure 6.

External and internal aspects of the fruit of Myrtillocactus. analyses performed on $M$. geometrizans showed that the plant is diploid. Its chromosome count is $2 n=22$, where $n=11$ [7].

\section{Agronomic aspects}

Myrtillocactus species belong to the Cactaceae family. Because of their Crassulacean acid metabolism, they are able to grow in the arid and semi-arid highlands of Mexico, where drought conditions are prevalent [8]. Field observations suggest that extreme freezing temperatures and high winter rainfall limit the distribution of these cacti in the Chihuahuan Desert [9] and other regions of Mexico. Otherwise, these species grow on mountain slopes with low-fertility soils, sometimes in competition with other plants. Myrtillocactus species also grow easily in good, well-drained, loamy soils, and tolerate the full summer sun [8]. Because of this ability, attempts have been made to introduce Myrtillocactus into other arid environments. Studies to evaluate their vegetative growth are now being conducted in the United Arab Emirates [10].

Myrtillocactus species have been propagated asexually by explants or cloning [11]. Although seed propagation is possible [12], the germination rate is very low, lower than in other common Cactaceae species [13]. However, both smooth and rough soil crusts have been found to positively affect seed germination in $M$. geometrizans [4]. Under controlled conditions, in vitro micropropagation of Myrtillocactus from apical and basal explants gives rise to high yields [14]. In some home gardens, young plants have been reproduced from seed or by grafting from branches of old plants.

According to Flores and Yeaton [9], when determining areas for plant cultivation, attention should be paid especially to minimum winter temperatures. If temperatures fall below $10^{\circ} \mathrm{C}$, a Myrtillocactus plant may not necessarily die, but its epidermis becomes irremediably damaged, with dark marks appearing that eventually develop into unproductive cork-like tissue. Exposure to full sunlight encourages the glaucous colouring of the stem. 
Cespedes et al. [6] reported that the common $M$. geometrizans is resistant to insect attack, a property that is apparently conferred by terpenoids (peniocerol 1, macdougallin 2 and chichipegenin 3). All these have been isolated from the plant's roots and aerial parts. Indeed, terpenoid extracts have shown insecticidal and insect-growth regulatory activity against two pests with wide distribution in Mexico: the fall armyworm (Spodoptera frugiperda), an important pest of maize crops; and Tenebrio molitor (Coleoptera) or mealworm beetle, a storage pest that attacks flours, ground meal and grains.

\section{Description of fruits and biochemical characterisation}

The fruits of Myrtillocactus species are globular in shape, and generally deep purple to bluish in colour when mature (figure 6 ). Myrtillocactus geometrizans yields the largest fruits, averaging $1.5 \mathrm{~cm}$ in diameter. The peel is thin and the flesh, which has a glowing red-wine colour, has a gel-like structure. The fruit contains numerous small black seeds $(<1 \mathrm{~mm})$ spread throughout the fruit's volume. The complete physico-chemical characterisation of the fruit has not yet been published, as most research has focused on the water-soluble red pigments, despite the fruit presenting other interesting physico-chemical characteristics. For example, as in other species of Cactaceae such as Opuntia ficus-indica, the mucilage and juice appear very useful for their rheological properties and as sources of dietary fibre $[15,16]$.

The water-soluble pigments of Myrtillocactus are betalains. Content in fresh fruit is reported to be $2.3 \mathrm{mg} \cdot 100 \mathrm{~g}^{-1}$ [17], which is similar to that of fresh cactus pear of Opuntia $\left(2.1 \mathrm{mg} \cdot 100 \mathrm{~g}^{-1}\right.$ [18], ranging from $5.12 \mathrm{mg} \cdot 100 \mathrm{~g}^{-1}$ for a fully red variety [19] to only $1.04 \mathrm{mg} \cdot 100 \mathrm{~g}^{-1}$ in a yellow variety). In contrast, betacyanin content in Myrtillocactus is much lower than the $40 \mathrm{mg} \cdot 100 \mathrm{~g}^{-1}$ found in another cactus species known as the red pitahaya (Hylocereus sp.) [20], or even the 30-60 mg $100 \mathrm{~g}^{-1}$ reported for red beet [21].
Analysing Myrtillocactus juice with HPLC shows four peaks, which correspond to betaxanthins (18.7\%), betanin (71.60\%), isobetanin $(3.09 \%)$ and an unidentified compound (6.61\%) [17]. The authors speculate that it may correspond to phyllocactin, a betacyanin found only in cactus fruit and flowers [22]. In contrast to the red pitahaya [20], the yellow pigment betaxanthin is present in Myrtillocactus juice.

Myrtillocactus juice, spray-dried at high temperatures and hydrated in acidified water solution at $0.014 \%(\mathrm{w} / \mathrm{v})$, was very stable over $5 \mathrm{~d}$ of storage at room temperature. That is, colour losses were only $7 \%$ at $\mathrm{pH} 4$, $1 \%$ at $\mathrm{pH} 5$ and $4 \%$ at $\mathrm{pH} 6$ versus $70 \%, 35 \%$ and $20 \%$, respectively, for red beet juice treated under the same conditions [17]. Betacyanin from Myrtillocactus was surprisingly stable (10\%-15\% loss over 5 d) under conditions of daylight, at $25^{\circ} \mathrm{C}, \mathrm{pH} 5.5$ and $0.1 \%$ ascorbic acid. The highest yields of betalain extracts were obtained by using an ethanol-HCl solution (99:1). However, the pigments were much less stable than when extracted with water [23].

Betalains from Myrtillocactus appeared most stable at $\mathrm{pH} 4.8-5.2$, where their average half-life at $25^{\circ} \mathrm{C}$ was $11,413 \mathrm{~min}$ (about $8 \mathrm{~d})$ and at $60^{\circ} \mathrm{C}, 83.5 \mathrm{~min}$. Ascorbic acid at $0.1 \%$ was the best catalytic agent for stabilising the compounds tested. The presence of $0.1 \%$ ascorbic acid helped double the halflife and decrease the energy of activation from $25.8 \mathrm{kcal} \cdot \mathrm{mol}^{-1}$ to $22.1 \mathrm{kcal} \cdot \mathrm{mol}^{-1}$ [23].

\section{Human consumption and commercial importance}

Myrtillocactus fruits are widely grown, usually with no or poor agronomic management. Farmer-gatherers from Otomí Indian communities in Hidalgo State (Mexico) traditionally use this natural resource for their own consumption and for commercialisation [24]. In the production season (June to September), the fruits are found in all public markets in the states where they are grown. Usually, the fruits are eaten either fresh or in processed forms such as ice cream, jam, and, more rarely, a sun-dried raisin-like 
product. Myrtillocactus flowers are also used to prepare a type of soup in some rural areas [5]. No literature exists on post-harvest physiology and technology; however, our preliminary results suggest a non-climacteric status of Myrtillocactus fruits; as a result, the fruit shows a short shelf life $(2 \mathrm{~d}$ at room temperature; $5 \mathrm{~d}$ stored at $5{ }^{\circ} \mathrm{C}$ ). On the other hand, we are currently developing technologies for the industrialisation of $\mathrm{Myr}$ tillocactus fruit to produce fruit powder, marmalade, raisin concentrates and juices.

The commercialisation of the fruit is restricted mainly to rural production areas in the states of Guanajuato, Hidalgo, Querétaro and San Luis Potosí. In these regions, almost $90 \%$ of adult rural dwellers say they are familiar with or have tasted the fruit, and $50 \%$ of children eat this fruit frequently [5]. Some analyses to test the innocuousness of the fruit's extracts were performed, using Wistar rats [25]. No toxicological or toxicokinetic effects were found for any dosage tested, which were as high as $5 \mathrm{~g} \cdot \mathrm{kg}^{-1}$ body weight. Neither did the fruit extracts show any metabolic effect; that is, over $7 \mathrm{~h}$, hepatocytes did not degrade betalain at any of the dosages tested. This showed that these components are not metabolised by hepatic cells. Moreover, the heartbeat rate of rats before and after ingestion of as much as $5 \mathrm{~g} \cdot \mathrm{kg}^{-1}$ of Myrtillocactus betalain extracts did not reveal significant differences. On the contrary, the betalains should demonstrate beneficial effects for human health, as suggested by the high antioxidant activity found for other Cactaceae species such as those of the Hylocereus genus [20].

\section{Conclusions}

This review establishes that published information on Myrtillocactus species is scarce and incomplete. This crop demonstrates high potential for drought-affected areas with relatively poor soils in Mexico and elsewhere in the world. In a global warming context, drought-resistant crops that efficiently use water and produce edible fruits deserve more attention. More research should therefore be carried out to assess the potential marketing interest of these fruits, particularly as the best way of preserving them and their biodiversity may add to their commercial value.

An international project (Producing Added Value from Under-utilised Crops or PAVUC), funded by the EU, is now assessing the entire biochemical composition of this fruit. As mentioned above, previous research has focused only on the colouring pigments to the exclusion of, for example, other phenolic compounds, vitamins or polysaccharides. Functional potential has not been assessed at all, even for Indian farmer-gatherers, for whom the fruits have high ethnic and traditional importance. Uses in traditional pharmacopoeia have not been described.

Studies to demonstrate antioxidant capacity and protective effect against certain diseases should also be addressed, particularly as the growing "functional" food market avidly seeks novel foods. In addition, the fruit supply chain itself should be studied to determine the possibilities of its development and integration into a regional or even international agribusiness supply chain. Likewise, the development of new derived products is important if convenient alternative uses in agro-industries are to be found. All these research lines would help to add value to a crop that may offer development alternatives to poor regions suffering drought, and, at the same time, provide food alternatives for consumers who want to improve and vary their diet with bio-diverse products.

\section{Acknowledgements}

Financial support from "Producing Added Value from Under-utilized Tropical Fruit Crops with High Commercial Potential" (PAVUC) (FP6-2003-INCO-DEV-2; Contract 015279. Sixth Framework Programme, Commission of the European Union) is acknowledged. 


\section{References}

[1] Console M., Myrtillocactus, Nuevo genere di Caccataceae, Boll. R. Orto Bot. Giard. Colon. Palermo, 1897, 1.

[2] Britton N.L., Rose J.L., Myrtillocactus eichlamii sp., The Cactaceae 2 (1920) 180-181.

[3] Britton N.L., Rose J.L., Myrtillocactus eichlamii sp., U. S. Herb. 12 (1909) 427.

[4] Rivera-Aguilar V., Godinez-Alvarez H., Manuell-Cacheux I., Rodriguez-Zaragoza S., Physical effects of biological soil crusts on seed germination of two desert plants under laboratory conditions, J. Arid Environ. 63 (2005) 344-352.

[5] Perez-Gonzáles S., Estudio etnobotánico, ecológico y de usos potenciales del garambullo (Myrtillocactus geometrizans) como base para su domesticación y cultivo, Cuad. Trab. Sist. Investig. Miguel Hidalgo, Queretaro, Mexico, 1999, 35 p.

[6] Céspedes C.L., Salazar J.R., Martínez M. Aranda E., Insect growth regulatory effects of some extracts and sterols from Myrtillocactus geometrizans (Cactaceae) against Spedoptera frugiperda and Tenebrio monitor, Phytochem. 66 (2005) 2481-2493.

[7] Cid R., Palomino G., Cytotypes and meiotic behavior in Mexican population of Myrtillocactus geometrizans var. geometrizans, Cytolog. 61 (1996) 343-348.

[8] Arias S., Gamma S., Guzman L., Flora del Valle de Tehuacán-Cuicatlán, Inst. Biol., Fasc. 14, UNAM, D.F., México, 1997, 23 p.

[9] Flores F.J.L., Yeaton R.I., The replacement of arborescent cactus species along a climatic gradient in the southern Chihuahuan Desert: competitive hierarchies and response to freezing temperatures, J. Arid Environ. 55 (2003) 583-594.

[10] El-Obeidy A.A., Introducing and growing some fruiting columnar cacti in a new arid environment, J. Fruit Ornam. Plant Res. 12 (2004) 127-136

[11] Malda G., Jimenez J., Commercial production of endangered cacti in arid zones, Gen Tech. Rep. Rocky Mt. For. Range Exp. Stn., USDA For. Serv., Fort Collins, CO, USA, 1987, 78-81.

[12] Reyes Santiago J., Castro Gonzales R., Mera Banda S., Brachet Ize C., A note on the establishment of a rural nursery for cacti and succulent production in the Valley del Mezquital, Hidalgo, Cact. Suc. Mex. 48 (2003) 118-126.

[13] Maiti R.K., Díaz Silva A., Peyron Gabriela P., García Guzman J., Cuervo Parra J.A.,
Sanchez Arreola E., Wesche Ebeling P., Miranda Pacheco P.G., Variability in seed viability of seven species of Cactaceae reserve biosphere of Tehuacan Cuitlan, Mexico, Crop Res. Hisar 23 (2002) 546-548.

[14] Gonzales Juarez J.L., Morales J.E., Lechuga Corchado J.A., Cruz Sosa F., In vitro reproduction of Myrtillocactus geometrizans (Martius) Console, Cact. Suc. Mex. 51 (2006) 36-45.

[15] Medina-Torres L., Brito-De La Fuente E., Torrestiana-Sanchez B., Katthain R., Rheological properties of the mucilage gum (Opuntia ficus indica), Food Hydrocoll. 14 (2000) 417424.

[16] Esquivel P., The fruits of the Cactaceae and potential as new materials, Agron. Mesoam. 15 (2004) 215-219.

[17] Reynoso R., Garcia F.A., Morales D., Gonzalez de Mejia E., Stability of betalain pigments from a cactacea fruit, J. Agric. Food Chem. 45 (1997) 2884-2889.

[18] Tesoriere L., Butera D., Pintaudi A.M., Allegra M., Livera M.A., Supplementation with cactus pear (Opuntia ficus-indica) fruit decreases oxidative stress in healthy humans: a comparative study with vitamin C, Am. J. Clin. Nutr. 80 (2004) 391-395.

[19] Butera D., Tesoriere L., Di Gaudio F., Bongiorno A., Allegra M., Pintaudi A.M., Kohen R., Livera M.A., Antioxidant activities of Sicilian prickly pear (Opuntia ficus indica) fruit extracts and reducing properties of its betalains: betanin and indicaxanthin, J. Agric. Food Chem. 50 (2002) 6895-6901.

[20] Vaillant F., Perez A., Davila I., Dornier R.M., Colorant and antioxidant properties of red Pitahaya, Fruits 60 (1) (2005) 1-7.

[21] Kanner J., Harel S., Graint R., Betalains - A new class of dietary cationized antioxidants, J. Agric. Food Chem. 49 (2001) 5178-5185.

[22] Piatelli M., Minale L., Pigments of centrospermae II. Distribution of betacyanins, Phytochem. 3 (1964) 547-557.

[23] Garcia Barrera F.A., Reynoso C.R., Gonzales de Mejia E.G., Stability of betalains extracted from garambullo (Myrtillocactus geometrizans), Food Sci. Technol. Int. 4 (1998) 115120.

[24] Granados Sanchez D., Hernandez H.J., The gathering system in a community of the valley of the Mezquital, Hidaldo, Rev. Chapingo Ser. Cienc. For. Ambiente 1 (1995) 109-115.

[25] Reynoso C.R., Giner T.V., Gonzalez de Mejía E., Safety of a filtrate of fermented garambullo fruit: biotransformation and toxicity studies, Food Chem. Toxicol. 37 (1999) 825830. 


\section{Myrtillocactus (cactaceae): las características botánicas, agronómicas, fisicoquímicas y químicas de sus frutos.}

Resumen - Introducción. En México, el nivel de producción de fruta de Myrtillocactus es importante, no obstante la fruta es subutilizada. A pesar de que el foco de interés se centra en su potencial como pigmento para alimentos, el fruto merece mayor atención debido a sus propiedades como alimento que presenta; sin embargo, la información sobre la composición fisicoquímica que existe es muy escasa. Con el fin de ofrecer una base para el desarrollo del cultivo de Myrtillocactus, ofrecemos la información disponible a la fecha. Descripción botánica. Se han identificado y reportado en la literatura cuatro especies de Myrtillocactus. Estas especies difieren en forma, color y otras características fenotípicas. En México, la especie predominante es $M$. geometrizans, pero $M$. shenckii también crece abundantemente a lo largo de las áreas áridas y semiáridas del país. Un estudio citológico realizado en $M$. geometrizans mostró que la planta es diploide $(2 \mathrm{n}=22)$. Aspectos agronómicos. La especie Myrtillocactus pertenece a la familia Cactaceae. Debido a su metabolismo ácido Crassulacean, son capaces de crecer en las zonas altas áridas y semiáridas de México. Las especies de Myrtillocactus has sido propagadas asexualmente a través de explantes o por clonación. Bajo condiciones controladas, la micropropagación in vitro de explantes apicales o basales da buen rendimiento. Para su cultivo, se debe poner especial atención a las bajas temperaturas invernales. Descripción del fruto y caracterización bioquímica. La fruta comestible es globular, con un diámetro que alcanza $1.5 \mathrm{~cm}$. La pulpa presenta una consistencia gelatinosa, de color que va de rojo a morado intenso. La caracterización química se ha enfocado principalmente en los compuestos betalaínicos, de éstos predominan las betaninas y betaxanthinas. Se han reportado contenidos de hasta $2.3 \mathrm{mg}$ de betaalina, $100 \mathrm{~g}^{-1}$ de pulpa. Aparentemente el pigmento es mas estable que el de la remolacha. Consumo humano e importancia económica. Durante la época de producción (Junio a Septiembre), la fruta se puede encontrar en todos los mercados públicos en los estados donde crece. El fruto se consume fresco o procesado en diferentes formas. La comercialización del fruto se restringe principalmente a las zonas rurales de producción en algunos de los estados de México. Conclusiones. Nuestra revisión establece que la información publicada sobre las especies de Myrtillocactus es escasa e incompleta. La planta es subutilizada, a pesar de sus propiedades nutricionales y potencial económico. Dado que se adapta fácilmente a condiciones severas de sequía, las especies de Myrtillocactus merecen mayor investigación.

México / Myrtillocactus / frutas / pigmentos / características agronómicas 